\title{
BANK SYARIAH DAN UMKM DALAM MENGGERAKKAN RODA PEREKONOMIAN INDONESIA: SUATU KAJIAN LITERATUR
}

\author{
Nik Amah \\ Pendidikan Akuntansi IKIP PGRI Madiun \\ Sigmaku87@gmail.com
}

\begin{abstract}
Abstrak
Penelitian ini merupakan literature review yang membahas tentang peran perbankan syariah dalam pemberdayaan UMKM di Indonesia. Upaya perbankan syariah dalam mengembangkan perekonomian negara adalah dengan memberikan pembiayaan pada sektor riil melalui usaha mikro kecil dan menengah. Seiring perhatian pemerintah terhadap perkembangan UMKM di Indonesia, perbankan syariah pun turut berpartisipasi dalam pemberdayaan UMKM tersebut. Sistem yang diterapkan oleh perbankan syariah sangat cocok untuk pengembangan UMKM karena perbankan syariah menerapkan sistem bagi hasil dalam memberikan bantuan pembiayaan. Perkembangan UMKM sangat berpengaruh pada perekonomian Indonesia maka dari itu sudah seharusnya UMKM ini diberdayakan dengan memberikan bantuan pembiayaan salah satunya melalui perbankan syariah.

Perbankan syariah telah melakukan segala sistem yang telah ditetapkan sesuai dengan UU No. 21 Tahun 2008 tentang perbankan syariah yaitu memberikan pembiayaan berdasarkan akad yang tidak bertentangan dengan prinsip syariah yaitu bagi hasil yang tidak merugikan pihak nasabah sehingga dapat menjalankan usahanya. Bank Indonesia (BI) mencatat penyaluran pembiayaan syariah pada sektor usaha mikro, kecil, dan menengah (UMKM) mencapai $70 \%$ dari total pembiayaan, atau sebesar Rp58 triliun hingga akhir September 2012. Hal ini membuktikan bahwa bank syariah memiliki peran penting dalam pemberdayaan UMKM.
\end{abstract}

Kata kunci: perbankan syariah, UMKM, perekonomian Indonesia

ABSTRACT

This research is study of the literature that discusses about the role of Islamic Banking in the empowerment of UMKM in Indonesia. The effort of Islamic banking in developing the national economy is to provide financing to the real sector through micro, small and medium enterprises. As the government's attention to the development of UMKM in Indonesia, Islamic banking also participated in the UMKM empowerment. The system adopted by Islamic banks is very suitable for the development of UMKM for implementing Islamic banking system to result in providing financial assistance. The development of UMKM affect on the Indonesian economy and therefore should UMKM are empowered by providing financial assistance through Islamic banking one.

Islamic banking system has done all that has been established in accordance with UU no. 21, 2008 concerning the financing of Islamic banking based contract that does not conflict with Islamic principles that the results are not detrimental to the client so that it can run its business. Bank Indonesia (BI) recorded the distribution of Islamic finance in the micro, small, and medium enterprises (MSMEs)/ UMKM to reach $70 \%$ of 
the total funding, or at Rp58 trillion by the end of September 2012. It is proved that Islamic banks focus more on empowering UMKM.

Keywords: islamic banking, UMKM, Indonesian economic

\section{PENDAHULUAN}

Jika kita menilik sejarah perkembangan ekonomi Negara Indonesia, kita bisa melihat betapa sering jatuh bangun mewarnai perekenomian Indonesia. Berharap untuk bangkit dari keterpurukan dan menyetabilkan perekonomian, Negara melakukan pinjaman modal kepada pihak asing. Ternyata langkah tersebut justru menjadikan bangsa tidak mandiri dan ketergantungan terhadap bantuan-bantuan pihak asing.

Hendaknya bantuan modal asing yang diperoleh bangsa Indonesia disalurkan secara tepat untuk kemandirian bangsa. Kemandirian suatu bangsa salah satunya ditandai dengan banyaknya wirausahawan dengan skala kecil menengah (UMKM) maupun yang berskala besar yang mampu memberikan sumbangsih dalam pergerakan ekonomi Negara. Kenyataan membuktikan bahwa selama krisis perekonomian, UMKM mampu bertahan menghadapi goncangan perekonomian. Selain UMKM tahan terhadap krisis, sektor UMKM nasional dikenal memiliki karakteristik positif seperti sektor yang menyerap tenaga kerja yang besar, mengakomodir peran masyarakat miskin dan dominan dalam struktur ekonomi. Berdasarkan data terakhir yang diperoleh, sektor tersebut memiliki jumlah pelaku usaha yang mencapai 51,3 juta unit usaha atau memiliki kontribusi sebesar 99\%, menyerap tenaga kerja 90,9 juta pekerja (97\%), menyumbang PDB sebesar Rp2.609 triliun (55,6\%), serta memberikan sumbangan devisa sebesar Rp183,8 triliun atau 20\% (Abiaqsa, 2011).

Melihat kenyataan tersebut hendaknya kita melihat peluang untuk menjaga keberlangsungan dan perkembangan UMKM sebagai solusi permasalahan ekonomi Negara. Menurut Febrinol, Tisna, dan Riyadian (2012) untuk mengatasi permasalahan Negara kita yang selalu mengandalkan ketergantungan kepada bantuan dari luar negeri salah satu langkah efektif adalah menggunakan keuangan mikro sebagai metode utama. Kontribusi pendekatan ini terdiri dari diversifikasi pelaku utama pembangunan adalah masyarakat (yaitu melalui pengembangan UMKM), pembiayaan pembangunan yang menggunakan sumber keuangan masyarakat sendiri serta menerapkan pendekatan pembangunan yang memiliki potensi untuk berlanjut (sustainable).

Untuk menyokong tumbuh dan berkembangnya UMKM di Negara ini, dibutuhkan peran serta aktif perbankan sebagai penghimpun dana dari masyarakat dan menyalurkannya kembali untuk masyarakat. Sebagaimana yang kita ketahui selama krisis ekonomi, bank syariah merupakan bank yang tidak terpengaruh oleh krisis tersebut. Bank syariah juga mendorong tumbuh dan berkembangnya sektor UMKM yang ditunjukkan dengan berbagai strategi seperti pembukaan pusat-pusat pelayanan pembiayaan mikro seperti gerai UMKM atau sentra UMKM.

Bank Indonesia (BI) mencatat penyaluran pembiayaan syariah pada sektor usaha mikro, kecil, dan menengah (UMKM) mencapai $70 \%$ dari total pembiayaan, atau sebesar Rp58 triliun hingga akhir September 2012. Bisa kita prediksi hasilnya ketika bank syariah bersinergi dengan UMKM, dimana keduanya memiliki ketahanan menghadapi krisis akan menjadikan perekonomian Indonesia semakin stabil. Jika kita analisis lebih mendalam, pengembangan UMKM akan membuka peluang pekerjaan, 
meningkatkan PDB, mengembangkan dunia usaha, serta penambahan APBN dan APBD melalui perpajakan.

\section{DEFINISI BANK SYARIAH}

Anshori (2008) menyebut bank syariah sebagai bank Islam (Islamic Bank) yang secara umum pengertiannya adalah bank yang pengoperasiannya mendasarkan pada prinsip syariah Islam. Anshori (2008) juga menyebutkan istilah-istilah lain untuk menamai entitas bank syariah, yaitu bank tanpa bunga (Interest- Free Bank), bank tanpa riba (Lariba Bank).

Menurut Undang-undang No.10 tahun 1998 yang diperbarui dengan Undangundang No. 21 tahun 2008 memberikan definisi bank syariah sebagai bank yang menjalankan kegiatan usahanya berdasarkan prinsip syariah dan menurut jenisnya terdiri atas Bank Umum Syariah dan Bank Pembiayaan Rakyat Syariah. Bab 1 pasal 1 Undang-undang No. 21 tahun 2008 memberikan penjelasan lebih lanjut mengenai Bank Umum Syariah yaitu bank syariah yang dalam kegiatannya memberikan jasa dalam lalu lintas pembayaran, sedangkan Bank Pembiayaan Rakyat Syariah yaitu bank syariah yang dalam kegiatannya tidak memberikan jasa dalam lalu lintas pembayaran. Jadi dapat disimpulkan bahwa bank syariah adalah bank yang menjalankan kegiatan usahanya berdasarkan prinsip syariah yang dalam kegiatannya tidak hanya memberikan jasa dalam lalu lintas pembayaran namun juga memberikan jasa dalam bidang pembiayaan.

\section{ASAS, TUJUAN, DAN FUNGSI BANK SYARIAH}

Bab 2 pasal 2 Undang-undang No. 21 tahun 2008 menjelaskan tentang asas yang melandasi perbankan syariah sebagai berikut, perbankan syariah dalam melakukan kegiatan usahanya berasaskan prinsip syariah, demokrasi ekonomi, dan prinsip kehatihatian. Asas ini mendasari setiap kegiatan perbankan syariah yang juga menjadikan bank syariah mampu bertahan di tengah krisis. Bank syariah memiliki tujuan untuk menunjang pelaksanaan pembangunan nasional dalam rangka meningkatkan keadilan, kebersamaan, dan pemerataan kesejahteraan rakyat (pasal 3 Undang-undang No. 21 tahun 2008).

Undang-undang No. 21 tahun 2008 juga memaparkan fungsi bank syariah dalam pasal 4 sebagai berikut:

1. Bank Syariah dan Unit Usaha Syariah wajib menjalankan fungsi menghimpun dan menyalurkan dana masyarakat.

2. Bank Syariah dan Unit Usaha Syariah dapat menjalankan fungsi sosial dalam bentuk lembaga baitul mal, yaitu menerima dana yang berasal dari zakat, infak, sedekah, hibah, atau dana sosial lainnya dan menyalurkannya kepada organisasi pengelola zakat.

3. Bank Syariah dan Unit Usaha Syariah dapat menghimpun dana sosial yang berasal dari wakaf uang dan menyalurkannya kepada pengelola wakaf (nazhir) sesuai dengan kehendak pemberi wakaf (wakif).

Dari pemaparan sebelumnya, fungsi bank syariah dapat dimanifestasikan sebagai intermediary agent yaitu pihak penengah antara masyarakat dengan masyarakat, dan antara masyarakat dengan pemerintah dalam hal pengumpulan dan penyaluran dana. Selanjutnya bank syariah juga berfungsi sebagai fund and investment manager (manajer investasi dan pembiayaan), penyedia jasa perbankan sebagaimana bank konvensional namun dengan catatan sesuai koridor syariah, dan pengelola fungsi sosial. 


\section{SEJARAH SINGKAT PERBANKAN SYARIAH}

Seperti dipaparkan oleh Febrinol, et al (2012) serta Nurhayati dan Wasilah (2013) sejarah singkat kemunculan perbankan syariah dapat diuraikan sebagai berikut, pertama kali dirintis oleh Ahmad El Najjar di Mesir dengan tanpa menggunakan kata Islam. Hal itu dikarenakan kekhawatiran bahwa rezim yang berkuasa saat itu akan melihat bank syariah sebagai gerakan fundamentalis. Ahmad El Najjar mengambil bentuk bank simpanan yang berbasis profit sharing di Kota Mit Ghamr pada tahun 1963, hingga tahun 1967 sudah berdiri sembilan bank dengan konsep serupa di Mesir. Setelah sukses berkembang di Mesir, pada tahun 1970-an sejumlah Bank berbasis Islam juga berkembang di Timur Tengah beberapa diantaranya Dubai Islamic Bank (1975), Bank of Sudan (1977), Philipine Amanah Bank (1973) dan Malaysia dengan Muslim Pilgrims Savings Corporation (1983).

Di Indonesia, perbankan syariah diprakarsai oleh Bank Muamalat Indonesia yang berdiri 1 November 1991 dengan $25 \%$ saham dimiliki oleh MUI. Bank Muamalat Indonesia mulai beroperasi pada tanggal 1 Mei 1992. Pada awal berkembangnya bank syariah di Indonesia, UU No. 7 Tahun 1992 sebagai dasar pengoperasian bank syariah hanya mengategorikan perbankan syariah sebagai bank dengan sistem bagi hasil. Pada saat itu belum ada landasan hukum syariah. Hingga diterbitkannya Undang- Undang No.21 Tahun 2008 tentang Perbankan Syariah pada tanggal 16 Juli 2008, barulah perbankan syariah mempunyai landasan hukum.

\section{DEFINISI USAHA MIKRO, KECIL, MENENGAH}

Undang-undang No. 20 Tahun 2008 memberikan definisi secara terpisah terhadap usaha mikro, usaha kecil, dan usaha menengah. Undang-undang No. 20 Tahun 2008 juga menetapkan kriteria-kriteria khusus (dalam pasal 6) untuk masing-masing kategori usaha tersebut. Pasal 1 menjelaskan usaha mikro adalah usaha produktif milik orang perorangandan / atau badan usaha perorangan yang memenuhi kriteria: smemiliki kekayaan bersih paling banyak Rp 50.000.000,00 (lima puluh juta rupiah) tidak termasuk tanah dan bangunan tempat usaha, atau memiliki hasil penjualan tahunan paling banyak Rp 300.000.000,00 (tiga ratus juta rupiah).

Pengertian usaha kecil adalah usaha ekonomi produktif yang berdiri sendiri, dilakukan oleh orang perorangan atau badan usaha yang bukan merupakan anak perusahaan atau bukan cabang perusahaan yang dimiliki, dikuasai, atau menjadi bagian langsung maupun tidak langsung dari usaha menengah atau usaha besar. Kriteria untuk usaha kecil yaitu: memiliki kekayaan bersih lebih dari Rp 50.000.000,00 (lima puluh juta rupiah) sampai dengan paling banyak Rp 500.000.000,00 (lima ratus juta rupiah) tidak termasuk tanah dan bangunan tempat usaha, atau memiliki hasil penjualan tahunan lebih dari Rp 300.000.000,00 (tiga ratus juta rupiah) sampai dengan paling banyak Rp 2.500.000.000,00 (dua milyar lima ratus juta rupiah).

Selanjutnya, usaha menengah mempunyai definisi sebagai usaha ekonomi produktif yang berdiri sendiri, dilakukan oleh orang perorangan atau badan usaha yang bukan merupakan anak perusahaan atau bukan cabang perusahaan yang dimiliki, dikuasai, atau menjadi bagian langsung maupun tidak langsung dari usaha kecil atau usaha besar. Usaha menengah memiliki kriteria sebagai berikut: memiliki kekayaan bersih lebih dari Rp 500.000.000,00 (lima ratus juta rupiah) sampai dengan paling banyak Rp 10.000.000.000,00 (sepuluh milyar rupiah) tidak termasuk tanah dan bangunan tempat usaha, atau memiliki hasil penjualan tahunan lebih dari Rp 
2.500.000.000,00 (dua milyar lima ratus juta rupiah) sampai dengan paling banyak Rp 50.000.000.000,00 (lima puluh milyar rupiah).

World Bank dalam tulisan di web departemen koperasi menetapkan kriteria usaha mikro, kecil, dan menengah berdasarkan jumlah tenaga kerja, jumlah pendapatan, dan jumlah aset. Kriteria usaha kecil dan menengah menurut World Bank meliputi:

1. Medium Enterprise, dengan kriteria :

a. Jumlah karyawan maksimal 300 orang

b. Pendapatan setahun hingga sejumlah $\$ 15$ juta

c. Jumlah aset hingga sejumlah $\$ 15$ juta

2. Small Enterprise, dengan kriteria :

a. Jumlah karyawan kurang dari 30 orang

b. Pendapatan setahun tidak melebihi $\$ 3$ juta

c. Jumlah aset tidak melebihi $\$ 3$ juta

3. Micro Enterprise, dengan kriteria :

a. Jumlah karyawan kurang dari 10 orang

b. Pendapatan setahun tidak melebihi $\$ 100 \mathrm{ribu}$

c. Jumlah aset tidak melebihi \$ 100 ribu

\section{ASAS, DAN TUJUAN USAHA MIKRO, KECIL, MENENGAH}

Ada beberapa asas yang dijadikan landasan oleh UMKM dalam menjalankan operasional usaha. Asas-asas tersebut meliputi kekeluargaan, demokrasi ekonomi, kebersamaan, efisiensi berkeadilan, berkelanjutan, berwawasan lingkungan, kemandirian, keseimbangan kemajuan, dan kesatuan ekonomi nasional (pasal 2 UU. No.21 Tahun 2008). Lalu tujuan dari UMKM sebagaimana termaktub dalam pasal 3 UU. No.21 Tahun 2008 adalah menumbuhkan dan mengembangkan usahanya dalam rangka membangun perekonomian nasional berdasarkan demokrasi ekonomi yang berkeadilan.

\section{PERAN UMKM DALAM MENGGERAKKAN EKONOMI}

Kenyataan membuktikan bahwa selama krisis perekonomian,UMKM mampu bertahan menghadapi goncangan perekonomian. Selain UMKM tahan terhadap krisis, sektor UMKM nasional dikenal memiliki karakteristik positif seperti sektor yang menyerap tenaga kerja yang besar, mengakomodasi peran masyarakat miskin dan dominan dalam struktur ekonomi. Berdasarkan data terakhir yang diperoleh, sektor tersebut memiliki jumlah pelaku usaha yang mencapai 51,3 juta unit usaha atau memiliki kontribusi sebesar 99\%, menyerap tenaga kerja 90,9 juta pekerja (97\%), menyumbang PDB sebesar Rp2.609 triliun (55,6\%), serta memberikan sumbangan devisa sebesar Rp183,8 triliun atau 20\% (Abiaqsa, 2011).

UMKM mempunyai peran yang strategis dalam menggerakkan pembangunan ekonomi nasional. Selain berperan dalam pertumbuhan ekonomi, menjaga kestabilan perekonomian, dan penyerapan tenaga kerja, UMKM juga berperan dalam pendistribusian hasil-hasil pembangunan, mengembangkan dunia usaha, dan penambahan APBN dan APBD melalui perpajakan. Karena UMKM memiliki peran penting dalam pengembangan usaha di Indonesia, dan juga merupakan cikal bakal dari tumbuhnya usaha besar hendaknya sektor ini memperoleh perhatian khusus tidak hanya dari pemerintah dan investor, namun juga dari pelaku UMKM itu sendiri serta pihak perbankan. Perhatian dalam bentuk upaya pengembangan UMKM harus dilaksanakan secara terintegrasi dengan pembangunan ekonomi nasional dan berkesinambungan. 


\section{PERAN BANK SYARIAH DALAM MENGEMBANGKAN UMKM}

Berkaca dari peristiwa krisis ekonomi yang membuktikan ketangguhan perbankan syariah dan UMKM, maka hendaknya perbankan syariah dan UMKM senantiasa bersinergi untuk membangun serta menggerakkan perekonomian Negara. Bank syariah adalah salah satu bank yang fokus terhadap pengembangan dan pemberdayaan sektor UMKM. Perbankan syariah beserta produknya sangat sesuai dengan karakter dunia usaha sektor UMKM. Bank syariah beroperasi dengan menerapkan prinsip bagi hasil yang berkeadilan tanpa menerapkan bunga atas transaksi sehingga tidak memberatkan sektor UMKM dalam hal pembiayaan usaha.

Data dari bank Indonesia sebagaimana dituliskan Abiaqsa (2011) bahwa sampai akhir 2010 terdapat 11 bank umum syariah (BUS), 23 unit usaha syariah (UUS) dan 151 bank pembiayaan rakyat syariah (BPRS), yang memiliki jaringan kantor mencapai 3.073 unit. Sampai akhir tahun 2010 peran perbankan syariah nasional diuraikan sebagai berikut: pembiayaan BUS dan UUS pada sektor UMKM telah mencapai Rp52,6 triliun atau porsinya (share) sebesar $77,1 \%$ dari seluruh pembiayaan yang diberikan BUS dan UUS ke sektor usaha. Pertumbuhan pembiayaan bagi UMKM tersebut mencapai $46,8 \%$ atau pertumbuhannya melebihi pertumbuhan total pembiayaan industri perbankan syariah itu sendiri. Kemudian jumlah rekening pembiayaan bagi UMKM mencapai lebih dari 600 ribu rekening atau porsinya mencapai 69,3\% dari total rekening pembiayaan perbankan syariah. Kemudian dituliskan oleh Munjin (2012) hingga akhir September 2012 tercatat penyaluran pembiayaan syariah pada sektor usaha mikro, kecil, dan menengah (UMKM) mencapai $70 \%$ dari total pembiayaan, atau sebesar Rp58 triliun.

Selain peran perbankan syariah membantu pembangunan perekonomian melalui pemberdayaan UMKM, perbankan syariah juga turut andil dalam menarik investor luar negeri ke Indonesia, terutama dari negara-negara Timur-Tengah. Adanya berbagai peluang investasi syariah di Indonesia, telah menarik minat investor dari negara-negara lain untuk menanamkan modalnya di Indonesia. Selanjutnya perbankan syariah sebagai salah satu wujud gerakan ekonomi syariah mendorong timbulnya perilaku ekonomi yang etis di kalangan masyarakat Indonesia. Ekonomi syariah adalah ekonomi yang berpihak kepada kebenaran dan keadilan dan menolak segala bentuk perilaku ekonomi yang tidak baik seperti sistem riba, spekulasi, dan ketidakpastian (Ujung, 2012).

\section{KESIMPULAN}

Penelitian ini merupakan studi literatur yang membahas tentang peran perbankan syariah dalam pemberdayaan UMKM di Indonesia. Mengacu beberapa literatur yang telah dibahas sebelumnya, maka disimpulkan bahwa dengan prinsip syariah Islam perbankan Syariah berperan penting dalam menggerakkan roda perekonomian Indonesia melalui pengembangan dan pemberdayaan UMKM. Baik secara langsung maupun tidak langsung, perbankan syariah juga menyokong peran penting UMKM dalam pertumbuhan ekonomi, menjaga kestabilan perekonomian, penyerapan tenaga kerja, mendistribusikan hasil-hasil pembangunan, mengembangkan dunia usaha, serta penambahan APBN dan APBD melalui perpajakan. Perbankan syariah juga turut andil dalam menarik investor luar negeri ke Indonesia dengan adanya berbagai peluang investasi syariah di Indonesia. 


\section{DAFTAR PUSTAKA}

Abiaqsa. 2011. Peran Perbankan Syariah dalam Pemberdayaan UMKM. http://abiaqsa.blogspot.com/2011/03/peran-perbankan-syariah-dalam.html. diunduh pada 29 Mei 2013.

Anshori, Abdul Ghofur. 2008. Sejarah Perkembangan Hukum Perbankan Syariah di Indonesia dan Implikasinya bagi Praktik Perbankan Nasional. La_Riba Jurnal Ekonomi Islam, Vol. 2, No. 2,pp. 159-172.

Febrinol, Tisna, dan Riyadian. 2012. Peran Bank Syariah dalam Mengembangan Usaha Kecil Menengah. http://ekonomi.kompasiana.com/bisnis/2012/09/25/peranbank-syariah-dalam-mengembangan-usaha-kecil-menengah-496026.html.

Munjin, Ahmad. 2012. Pembiayaan Syariah ke sektor UMKM yang telah mencapai 70\% hingga September 2012, dinilai belum cukup. Butuh juga kejelasan peran dari pemerintah dan bank sentral. Seperti apa? http://m.inilah.com/read/detail/1923343/menakar-kontribusi-bank-syariah-padasektor-riil. diunduh pada 29 Mei 2013.

Nurhayati, Sri dan Wasilah. 2013. Akuntansi Syariah Di Indonesia, Edisi 3. Jakarta: Salemba Empat,

Ujung, Ramona. 2012. Peran Bank Syariah dalam Pembangunan. http://ramonauzunk13.blogspot.com/2012/02/peran-bank-syariah-dalampembangunan.html

Undang-undang No.10 tahun 1998 tentang Perubahan Atas Undang-Undang No. 7 Tahun 1992 tentang Perbankan.

Undang-undang No. 20 Tahun 2008 tentang Usaha Mikro, Kecil, dan Menengah.

Undang-undang No. 21 tahun 2008 tentang Perbankan Syariah. 